\title{
Nasolacrimal Duct Obstruction in Adults
}

\author{
Anila Monka ${ }^{1}$, Sulejman Zhugli ${ }^{2}$ \\ University Hospital Centre "Mother Theresa" Tirana, Albania
}

\begin{abstract}
Evaluation of the results of DCR's external technique with the use of silicon tubes in clinical improvement of patients and the factors that affect in preventing relapses. The study was conducted at the Department of Ophthalmology at UHC "Mother Theresa" which is tertiary center. One hundred thirty seven patients participated in the study, whose mean age was $56.1( \pm 15)$ with a range from 34 to 81 years. 22 (16\%) of the patients were males and 115 (84\%) females $p<0.05)$. Five (3.6\%) of total patients experienced a relapse while the success rate $96.4 \%$. The success rate is 3.6 times higher external dacriocystorhinostomy as compared to patients treated without this technique $(O R=3.6,95 \%$ CI 1.46- 8.62, p<0.01). External DCR with silicone intubation has a high success rate. Disorders of the lacrimal system can be diagnosed from the history, signs symptoms, clinical examination, lab studies, imaging studies and other tests
\end{abstract}

Keywords: dacriocystorhinostomy silicone tubes, nasolacrimal duct obstruction, adults

\section{Introduction}

Obstruction of the nasolacrimal duct: It might becongenital or aquired. The congenital one has been discussed in the congenital anomalies of the lacrimalsystem. Acquired nasolacrimal duct obstruction, can occur at any age and is divided into primary and secondary. The primary acquired nasolacrimal duct obstruction (PANDO) is caused by inflammation, or fibrosis without any precipitating cause (1). It is more common in middle-aged and elderly females. They demonstrated using CT scans, that women have significantly smaller dimensions in the lower nasolacrimal fossa and middle nasolacrimal duct. They noted that changes in the anteroposterior dimensions of the bony nasolacrimal canal coincide with osteoprotic changes throughout the body (2). These may explain the prevalence of the disease in the middle-aged and elderly females. Hormonal changes that bring about a generalized deepithelizationin the body may be the same within the lacrimal duct. An already narrow lacrimal fossa in women predispose them to obstruction by the sloughed off debris.113 The secondary acquired lacrimal duct obstruction (SALDO) is caused by inflammation or fibrosis with precipitating cause such as infectious, inflammatory, neoplastic, traumatic, or mechanical factors.94 Infections with bacteria, viruses, fungi and parasites have been implicated as causes of SALDO. Bacteria such Actinomyces, propioniobacterium, Fusobacterium, Bacteroides, Mycobacterium, and Chlamydia specieshave been associated with lacrimal drainage obstruction. Other bacteria include Nocardia, Enterobacter, Treponema pallidus, and Staphylococcus aureus. Viral causes are seen with herpetic infection (e.g Herpes simplex, Herpes zoster, Chichenpox, epidemic keratoconjunctivitis) (3).Fungi may obstruct lacrimal passages by forming stone (dacryolith) or cast. Species associated with obstruction are Aspergillus, Candida, Pityrosporum andTrichophyton. Parasitic obstruction is rare but is reported in patients infected with Ascarislumbricoids, which enters the lacrimal system through the valve of Hassner (4). Inflammation may be endogenous or exogenous in origin. Wagener granulomatosis and sarcoidosis are 2 examples of conditions that lead to obstruction due to progressive inflammation within the mucosa of the nasolacrimal passages. Other endogenously arising inflammation associated with lacrimal obstruction are cicatricial pemphigoid, sinus histiocytosis, Kawasaki disease and scleroderma $(5,6)$.Exogenous causes of cicatricial lacrimal drainage obstruction are systemic chemotherapy, bone marrow transplantation and radiation. Trauma can lead to scarring and obstruction of the lacrimal passage which might be iatrogenic following aggressive lacrimal probing, orbital decompression surgery, paranasal, nasal and craniofacial procedures. A number of cases of dacryostenosis have been reported after cosmetic rhinoplasty $(7,8)$. Non- iatrogenic traumatic causes are either blunt or sharp trauma which most commonly involves the canaliculus, lacrimal sac, and nasolacrimal duct (9) squamous cell carcinoma can cause obstruction for the distal aspect of the nasolacrimal duct $(10,11)$.External DCR in which the lacrimal sac is approached from outside via a short skin incision, a little bit of bone between the tear sac and the nose is removed in order toreach inside the nose, the tear sac is opened and stitched to the lining of the nose (nasal mucosa), a soft silicone tubing is placed from the upper and lower puncti though the tear ducts into the nose temporarily to keep the passage open. These tubes are usually removed between six and eight weeks after the operation (12).

\section{Materials and Methods}

A total 137 patients who had DCR surgery between 2013and 2014 were prospectively reviewed in University Hospital Centre "Mother Theresa" in Tirana, Albania which is a tertiary referral hospital. All patients had primary nasolacrimal duct obstruction and no previous surgery for nasolacrimal duct obstruction. A complete ophthalmologic examination was performed. The patency of lacrimal drainage system was evaluated with lacrimal syringing. All patients were examined by otorhinolaryngology department and when needed assessed with computed tomography. Informed consent was taken from all patients. Age, gender, laterality, andlacrimal irrigation in the third month visit were recorded. Surgical success was accepted as the patency of the formed ostium with lacrimal syringing/irrigation. All cases were done by a single surgeon (AG). Exclusion criteria were canalicular stenosis, epiphora due to adnexal, corneal, conjunctival diseases, and age less than 20 years of age.Descriptive methods and independent t-test were used 


\section{International Journal of Science and Research (IJSR) \\ ISSN (Online): 2319-7064}

Index Copernicus Value (2013): 6.14 | Impact Factor (2014): 5.611

for statistical analyses and a $\mathrm{p}$ value $<0.05$ wasaccepted as significant.

\section{Results and Discussion}

One hundred thirty seven patients participated in the study, whose mean age was $56.1( \pm 15)$ with a range from 34 to 81 years. $22(16 \%)$ of the patients were males and $115(84 \%)$ females $\mathrm{p}<0.05)$. The mean age of men was $57.1( \pm 9.0)$ years (range 29-81 years), while women is changing age $50.5( \pm 9.8)$ years (range $32-70$ years) between them statistically significant $(\mathrm{t}=3.9 \mathrm{p}<0: 01)$. Sociodemographic characteristics of patients are shown in table 1 . The ratio of patients $\geq 60$ years with patients $<60$ years was $1.1: 1$. Most of the patients, 108 or $79 \%$ of them live in urban areas while $29(21 \%)$ of them live in rural areas, with statistically significant difference between them $(p<0: 01)$. It is noted a predominance of patients in the age group 51-60 years old with $36(26.6 \%)$ of cases. Seven or $5.3 \%$ of patients suffered from acute DC, 24 (17.5\%) suffered from chronic DC, 96 $(70.2 \%)$ of chronic purulent DC and 10 patients from phlegmonoussacus'slacrimalis.

External dacriocystorhinostomy with silicone tube was carried out in all patients. The success rate and percentage of relapse were evaluated. Five (3.6\%) of total patients experienced a relapse whilethe success rate $96.4 \%$. The success rate is 3.6 times higher externaldacriocystorhinostomy as compared to patients treated without this technique $(\mathrm{OR}=3.6,95 \% \mathrm{CI}$ $1.46-8.62, \mathrm{p}<0.01)$. The presenting signs and symptoms of nasolacrimal duct obstruction include epiphora, conjunctivitis, and mucoid discharge. Dacryocystitis may develop when bacterial growth occurs in the stagnant fluid of the lacrimal sac. Whereas acute dacryocystitis is usually characterized by tender preseptalcellulites, chronic dacryocystitistypically manifests as painless purulent reflux from the lacrimal sac. A rare risk of untreated, chronic dacryocystitis secondary to an acquired nasolacrimal duct obstruction is orbital cellulites (13). Dacryocystorhinostomy (DCR) is a surgical method for treatment of the lacrimal excretory system obstructon. Obstruction of the passage of tears from the puncti through canaliculi, lacrimal sac and finally the nasolacrimal duct down to the nose can lead to stagnation of tear in the point before the obstruction, with continuous tearing and the resultant infection with continuous pus discharge into the eye, which may lead to ocular and peri-ocular infections with the possible sequelae of vision -or even - life threatening complications (14). When this infection is established in the lacrimal excretory parts, this leads usually to the destruction and fibrosis of the thin delicate canal which penetrates the tissue (including the bone) to excrete tears in the inferior part of the lateral wall of the nose, at this point there is no solution other than creating a new window through those tissues to permit tears to be excreted in the nose again (15). Since the introduction of external DCR subsequent modifications have ensured a high success rate and it remains the gold standard for treating of epiphora caused by nasolacrimal duct obstruction (16).

\section{Conclusions}

External DCR with silicone intubation has a high success rate.Disorders of the lacrimal system can be diagnosed from the history, signs symptoms, clinical examination, lab studies, imaging studies and other tests. The patient should be evaluated in a systemic manner and not all steps are needed because the diagnosis may be apparent with some simple tests.

\section{References}

[1] Vieira GS, Xavier ME. Results and complications of bicanalicular intubation in external dacryocystorhinostomy. Arq Bras Oftalmol. 2008;71(4):529-33.

[2] Coban DT, Beden U, Sonmez B, Erkan D. Outcomes of external dacryocystorhinostomy and effects of the incision type on cosmetic and functional outcomes. J Clin Anal Med. 2011;2(1):21-4

[3] Anderson RL, Edwards JJ. Indications, complications and results with silicone stents. Ophthalmology 1979;86(8):1474-87

[4] Ozay S, Bakbak B, Onder F. [Silicone tube indications, external dacryocystorhinostomy]. MN Oftalmoloji $2005 ; 12: 152-5$

[5] Bayhan SA, Recep ÖF, Düzen B, Hasıripi H [The results of external dacryocystorhinostomy operations performed with single flap and double flaps]. T Oft Gaz. 2008;38:371-4

[6] Choung HK, Khwarg SI. Selective non-intubation of a silicone tube in external dacryocystorhinostomy. ActaOphthalmolScand 2007;85(3):329-32.

[7] Madge SN, Selva D. Intubation in routine dacryocystorhinostomy: why we do what we do. Clin Experiment Ophthalmol 2009; 37(6): 620-3.

[8] Saiju R, Morse LJ, Weinberg D, Shrestha MK, Ruit S. Prospective randomised comparison of external dacryocystorhinostomy with and without silicone intubation. Br J Ophthalmol. 2009;93(9):1220-2.

[9] Marcet, Marcus M., Andrew KT Kuk, and Paul O. Phelps. "Evidence-based review of surgical practices in endoscopic endonasaldacryocystorhinostomy for primary acquired nasolacrimal duct obstruction and other new indications."Current opinion in ophthalmology 25.5 (2014): 443-448.

[10] Sodhi PK, Pandey RM, Malik KP. Experience with bicanalicular intubation of the lacrimaldrainage apparatus combined with conventional external dacryocystorhinostomy. JCraniomaxillofacSurg 2003; 31(3): 187-90.

[11] Vieira GSS, Xavier ME. Resultados e complicações da entubaçãobicanalicularem dacriocistorrinostomia externa. Arq Bras Oftalmol 2008; 71(4): 529-33.

[12] Saiju R, Morse LJ, Weinberg D, Shrestha MK, Ruit S. Prospective randomized comparisonof external dacryocystorhinostomy with and without silicone intubation. British Journal ofOphthalmology 2009; 93(9): 1220-2.

[13] Boboridis KG, Bruce C, Rose GE. Outcome of external dacryocystorhinostomy combinedwith membranectomy of a distal canalicular obstruction. Am J Ophthalmol. 2005; 139(6):1051-5

[14] Hurwitz JJ, Merkur S, De Angelis D. Outcome of lacrimal surgery in older patients. Can JOphthalmol $2000 ; 35(1): 18-22$. 


\section{International Journal of Science and Research (IJSR) \\ ISSN (Online): 2319-7064}

Index Copernicus Value (2013): 6.14 | Impact Factor (2014): 5.611

[15]Liu D, Bosley TM. Silicone nasolacrimal intubation with mitomycin-C: a prospective,randomized, doublemasked study. Ophthalmology 2003; 110(2): 306-10.

[16] Costa MN, Marcondes AM, Sakano E, Kara-José N. Endoscopic study of the intranasal ostium in external dacryocystorhinostomy postoperative. Influence of saline solution and 5-fluorouracil. Clinics 2007; 62(1): 41-6.

Table 1: Sociodemographic characteristics of patients

\begin{tabular}{|c|c|c|c|}
\hline Variablat & $\mathbf{N}$ & $\mathbf{\%}$ & $\mathbf{P}$ \\
\hline Gjinia & & & \\
\hline Femra & 115 & 84.0 & \\
\hline Meshkuj & 22 & 16.0 & \\
\hline Grupmosha, vite & & & $<0.01$ \\
\hline$\leq 40$ & 17 & 12.4 & \\
\hline $41-50$ & 24 & 17.5 & \\
\hline $51-60$ & 36 & 26.6 & \\
\hline $61-70$ & 28 & 20.4 & \\
\hline$>70$ & 32 & 23.4 & \\
\hline Vendbanimi & & & $<0.01$ \\
\hline Urban & 108 & 78.8 & \\
\hline Rural & 29 & 21.2 & \\
\hline
\end{tabular}

